\title{
Determinants of Capital Structure: A Conceptual Understanding of Oil and Gas Firms in Malaysia
}

\author{
Hana Halini Hamzah ${ }^{1}$, and Maran Marimuthu ${ }^{1}$ \\ ${ }^{1}$ Universiti Teknologi Petronas, Department of Management and Humanities, 32610, Bander Seri Iskander, Perak, Malaysia
}

\begin{abstract}
Since the introduction of Modigliani and Miller's (1958) proposition of irrelevance capital structure principle, a wide debate on capital structure has emerged. The literature on the topic has been studied intensively as they are increasingly recognized as the central of the corporate finance field. In addition, an in-depth study focusing on the determinants of capital structure has also increased as it acts as an important indicator for the firms in making capital structure decision. However, the results remain inconclusive making the determinants of capital structure not clearly understood, thus suggesting a need for further studies. Therefore, the aim of this study is to discuss the relationship of determinants of capital structure, specifically among oil and gas firms in Malaysia. The findings of this study will increase the understanding of the phenomena, thus assisting researchers in conducting further studies and guiding decision makers in making capital structure decision.
\end{abstract}

\section{Introduction}

The last decade has seen an increase in the number of studies on capital structure. The capital structure is defined as the composition of debt and equity that firms use to finance its business activities (Suarez, 2016). The capital structure of firms can determine the weighted average cost of capital (WACC) where the lowest WACC is favourable to increase the firm value (Karadeniz, Yilmaz Kandir, Balcilar, \& Beyazit Onal, 2009). However, the question raised by Myers (1984), "how do firms choose their capital structures?" still remains with no clear answer (Haron, 2014). Therefore, intensive studies on determinants of capital structure that act as significant indicators for the firms to issue debt or equity have been widely carried out. Nevertheless, there is no consensus among the results presented and the results fail to demonstrate similarities among each other, suggesting a need for further studies.

In addition, this study is also motivated by several other reasons. Firstly, prior studies on determinants of capital structure widely focuses on developed countries (Rajan \& Zingales, 1995). Subsequently, the focus of the studies has extended to the developing countries (Booth, Aivazian, Demirguc - Kunt, \& Maksimovic, 2001) as these countries have different institutional settings. According to Bekaert and Harvey (2017) developing countries are still heavily depending on the bank as their main source of financing. Thus, there is not enough evidence on how theories that have been developed using data incorporated from the developed countries can be applied to the firms operated in developing countries.

Secondly, different types of firms have different ways of making capital structure decision (Bauer, 2004). However, most of the studies conducted incorporated non-financial firms as an indicator to study capital structure decision (Kumar, Colombage, \& Rao, 2017). This indicates they do not separate their data based on the firms' type but instead treating all types of firms as a homogenous group. Consequently, each type of firms' impact is cannibalized by some other dominant type of firms. Meanwhile, given the importance of oil and gas firms in the world, it is surprising that the capital structure for oil and gas firms have been less intensively discussed in the academic literature, though oil and gas firms are one of the largest and major players in the global economy and it is the world's most capital-intensive industry (Karl, 2007; Oghenekohwo, Theresa, \& Alice, 2015). Furthermore, the rise of 4th industrial revolution requires firms to upgrade existing technology. This is especially for oil and gas firms that requires high technology (Rawl, 1987) and eventually requires more capital. However, oil and gas firms are well known for the volatility of its earnings due to the fluctuation of oil and gas prices. The fluctuation of the price is to respond to the demand and supply (Geng, Ji, \& Fan, 2017; Gisser \& Goodwin, 1986; Mitchell \& Mitchell, 2014). Thus, firms must be more innovative in making their capital structure decision in such a way that is not only able to minimize its cost of capital but also to avoid excessive use of debt. This is because an excessive repayment of debt coupled with low earnings can drain away any available cash, putting

\footnotetext{
Corresponding author: hana_16005304@utp.edu.my
} 
pressure on financial. Therefore, it brings to the rise of the need to understand how oil and gas firms make capital structure decision.

The structure of this study is as follows: Section two provides an overview of Malaysian Economy. Section 3 discusses the theories of capital structure. Section 4 discusses the determinants of capital structure.

\section{Overview of Malaysian Economy}

Malaysia is a developing country located in Asia Pacific region (The World Bank, 2016). Despite the external shock, Malaysia remains resilience and continues to perform well (IMF, 2018). One of the important engines behind Malaysia's growth is oil and gas firms. In the year 2009, oil and gas firms contributed to 41.3 percent of Malaysia's income through dividend and corporate income tax payments as well as sales tax and export duty collected (NTP, 2017), making it as Malaysia's central for economic growth (EIA, 2017). In fact, one of Malaysia's oil and gas firms, Petroliam Nasional Berhad (PETRONAS), is the only Malaysian firm that appears in the Global Fortune 500 companies. Therefore, as to establish a more favourable economic environment, the government in the year 2010 has identified oil and gas firms together with energy firms to form oil, gas and energy sector as one of the main drivers to the economy and became central to the plans to transform Malaysia into developed country status (ETP, 2012).

Oil, gas and energy sector dominates the Malaysian economy. Yet, in the year 2016, the government of Malaysia has reduced dependency on the sector (NTP, 2016). This is because oil and gas firms account for only 15.1 percent of the total government revenue for the period of 2017 (NTP, 2017). It shows a significant decrease from 41.1 percent in the year 2009 to 15.1 percent in the year 2017. While the contribution of non-oil and gas firms to government revenue has shown an increase (NTP, 2017), in terms of GDP contribution, wholesale and retail sector which is a non-oil and gas firms has overtaken oil, gas and energy sector as the single largest contributor to Malaysia's GDP (NTP, 2016). Other non-oil and gas firms such as firms categorized under electrical and electronics, food and beverages, and agriculture sectors have seen a significant increase in GDP amounted 0.02 percent, 0.26 percent, and 0.06 percent respectively (NTP, 2016, 2017). The reduction of government revenue and GDP contribution from oil and gas firms are mainly due to the volatility of OG firms' earnings (NTP, 2017). However, the government has retain oil and gas firms together with energy firms (oil, gas and energy sector) as one of the main drivers of the economy to transform Malaysia into developed country status (NTP, 2017). As oil and gas firms face the volatility of earnings, therefore, cost minimization becomes a critical factor for oil and gas firms to compete effectively (Del Sala, 2015; Rawl, 1987) especially with other firms in transforming Malaysia into a developed country status. Consequently, this provides a scope to study the determinants of capital structure for oil and gas firms. In addition, examining the impact of determinants of capital structure for oil and gas firms and how it may differ with other non-oil and gas firms within the context of non-financial sectors in Malaysia is essential to enable oil and gas firms to remain as one of the main drivers in transforming Malaysia into a developed country status.

\section{Theories of Capital Structure}

In 1958, two professors, Modigliani and Miller had introduced a modern thinking of capital structure theory known as Modigliani-Miller (MM) theory. This theory claims that, under a perfect market assumption where there are no taxes, no information asymmetric, and no agency cost, capital structure is irrelevant to the firm value (Myers, 2001). This implies that firms are free to choose any combination of debt and equity because it does not bring any differences on the firm value. However, this theory sparked an argument among researchers in the financial field and had caused several criticisms. This is because this theory seems unrealistic and only works under a frictionless market which does not hold and exist in the real world (Ahmed Sheikh \& Wang, 2011). Since then, various theories of capital structure have been introduced. Although the literature covers a wide variety of theories, this paper will focus on the two most dominants theories repeatedly throughout the literature review. The theories are (1) Trade-off theory emphasizing on the trade-off between the costs and the benefits of debt and (2) Pecking Order theory which emphasizes on information asymmetric.

Trade-off theory postulates that there exists an optimal capital structure by focusing the benefits of debt and the costs of debt (Atiyet, 2012). Therefore, in this theory, the optimal capital structure can be achieved by balancing the benefits and the costs of debt. This theory was employed to clarify that firms finance its business activities with the combination of debt and equity (Tongkong, 2012). The benefits of debt are (1) debt tax shield and (2) able to overcome the manager-shareholders conflict (Atiyet, 2012; Myers, 2001). The cost of debt is in term of (1) potential bankruptcy cost or reorganization and (2) agency cost of outside debt (Myers, 2001). This theory also has several specific implications which are: (1) risky firms should issue less debt than safer firms, and (2) firms with tangible and marketable assets should issue more debt compared to firms with intangible and specialized assets (Myers, 1984). Moreover, this theory suggests that firms in need of financing should issue 
debt when their leverage is below the optimal, and seek for equity when the leverage ratio is more than optimal (R. Huang \& Ritter, 2005).

Pecking Order theory explains that firms make capital structure decision by considering the information asymmetric that exist between various parties of firms such as managers, creditors, and external investors (Myers \& Majluf, 1984). An issuance of new equity to finance investment opportunities with positive net present value (NPV) can be overvalued or undervalued but only managers know the inside information than outsiders (Myers \& Majluf, 1984). Hence, managers who act in the interest of existing shareholders will refuse to issue undervalued equity despite the new investment opportunities having positive NPV (Myers, 2001) because undervalued equity will transfer values from existing shareholders to the new shareholders, hence, as the alternative, firms will issue debt rather than equity. For this reason, issuing an equity also acts as a signal to investors that equity is overvalued, hence a sceptical investor will only buy the equity when the equity is sold at discount (Myers, 2001). Therefore, in this theory, firms have preferred order source of funds to finance the operation and growth. The order starts with retained earnings, and in the absence of it, the firm will borrow and lastly issue equity as a last resort (Myers \& Majluf, 1984). The order of the source of funds interpreted that firms with high profit will have less leverage in their capital structure (Tongkong, 2012). In addition, by issuing debt and equity it gives a different message to investors. Debt signal to investors that the firms are confident that they can service the debt, while equity shows that the firms are overvalued and this will lead to a fall in share price (Myers \& Majluf, 1984).

Trade-off theory and Pecking Order theory emphasize a different aspect of making the capital structure decisions. Based on the study conducted by Ahmed Sheikh and Wang (2011), profitability, assets tangibility, and liquidity are in line with Pecking Order theory, while earnings volatility is in line with Trade-off theory. Sofat and Singh (2017) reported that profitability is in line with Pecking Order theory, while tangibility and earnings volatility are in line with Trade-off theory. It shows that there are no specific theories that can explain capital structure decision inclusively. Nevertheless, these theories do provide some understanding on how firms make capital structure decision.

\section{Determinants of Capital Structure}

Until now, firm-specific factors are the most influential determinants in influencing the capital structure decision. Firm-specific factors such as profitability, tangibility, growth opportunities, earnings volatility, and liquidity are found commonly and consistently considered in the literature. In short, these five firm-specific factors were repeatedly identified as the most influential factors that have an influence on the capital structure decision. Thus, these firm-specific factors appear to be important factors in influencing the capital structure decision. In addition, Booth et al. (2001) had confirmed the homogeneity of determinants of capital structure in developing countries and developed countries regardless of the institutional settings. This implies that the factors in influencing capital structure decision in developed countries are also found to be relevant in explaining developing countries. It is also confirmed by a study done by Sofat and Singh (2017).

\subsection{Profitability}

According to Baker and Wurgler (2002), profitability is associated with the availability of internal fund. It is one of the most important factors. From the perspective of Trade-off theory, highly profitable firms should increase debt. This is because interest on the debt is tax deductible. As the use of debt is able to reduce the amount of tax, hence it can increase firms' value. Therefore, Trade-off theory predicts that profitability has a positive relationship with leverage level suggesting that profitable firms have higher leverage level.

Vo (2017) found evidence to support the Trade-off theory. However, the positive relationship is only for longterm debt but not for short-term debt. This implies that firms tend to borrow long-term debt while at the same time reducing the use of short-term debt. On the other hand, Oino and Ukaegbu (2015), found a contrasting result in which profitability has a positive relationship only with short-term debt for the firms in Nigeria.

Contrasting to the Trade-off theory, Pecking Order theory argued that profitable firms will opt for the internal fund. According to the theory, profitable firms have their own preference and they will rely more on internal rather than on external fund to finance their business activities. They will prefer to use retained earnings first, then prefer debt over equity when retained earnings were not available (Myers, 2001). This implies that profitable firms prefer to exclude debt as their financing choice and only include debt when the need for funding is greater than available retained earnings, hence suggesting that profitability negatively impacts on leverage level.

Most of the studies (Hussain, Hamza, \& Miras, 2015; Kayo \& Kimura, 2011; Matias \& Serrasqueiro, 2017; Rajan \& Zingales, 1995; Sabir \& Malik, 2012; Titman \& Wessels, 1988) had concluded that profitability has a negative relationship with leverage level, hence confirms the Peking Order theory. This indicates that profitable firms are less likely to choose debt when making capital structure decision. This is because the use of retained earnings can avoid the issuance cost of debt and equity. According to Chipeta and Deressa (2016), in developing countries, the capital markets are not well-developed. It is supported by Vo (2017), Bekaert and Harvey (2017) that firms in developing countries heavily rely on banks as a major source of financing. This suggests that developing countries have limited source of financing and it would lead to the higher cost of capital. Profitability can be measured by using earnings before interest and tax to total assets (G. Huang \& Song, 2006). 


\subsection{Tangibility}

Asset tangibility is defined as fixed assets as the proportion of the total assets (Hall, 2012). It can be used as collateral and security for the creditors who had given the debt. According to Hall (2012), the existence of collateral can help creditors to determine the riskiness of borrowers and used as a resort in the event of bankruptcy. Furthermore, less financial distress costs are expected with the existence of tangible assets (Chipeta \& Deressa, 2016) as tangible assets can be converted into cash in the case on any cash requirement situation. Thus, creditors will feel confident that the firm will be able to meet the obligation to pay the debt and at the same time firms are able to reduce the financial distress cost. In accordance to the Trade-off theory, firms' optimal capital structure can be achieved by balancing the marginal benefits and the marginal costs of debt. Therefore, as the marginal benefits of further increase in debt (debt tax shield) exceeds the marginal cost of debt, firms should increase their leverage level. Thereby, assets tangibility has a positive relationship with leverage level, suggesting that firms with high assets tangibility have low level of debt. In contrast, Pecking Order theory predicts that assets tangibility has a negative relationship with leverage level. The negative relationship shows that the more tangible assets owned by a firm, the lesser the firm is prone to the asymmetric information problem (Baltaci \& Ayaydin, 2014). Therefore, firms prefer to issue equity as the cost of equity is typically cheaper than debt.

Several studies confirmed that assets tangibility has a positive relationship with leverage level which is in line with the Trade-off theory (Berkman, Iskenderoglu, Karadeniz, \& Ayyildiz, 2016; Deesomsak, Paudyal, \& Pescetto, 2004; Dhingra \& Dev, 2016; Hussain et al., 2015; Md-Yusuf, Mohammad Yunus, \& Md Supaat, 2013; Sabir \& Malik, 2012; Vo, 2017). Matias and Serrasqueiro (2017), Vo (2017), Chipeta and Deressa (2016), Oino and Ukaegbu (2015), Proença, Laureano, and Laureano (2014), Taddese Lemma and Negash (2013), Ting and Lean (2011) showed evidence that assets tangibility has a positive relationship with long-term debt as posited by Trade-off theory, and it has a negative relationship with short-term debt as posited by Pecking Order theory. Thus, it suggests that most of the firms use tangible assets as collateral to issue long-term debt, hence being less dependent on short-term debt. It is supported by Ahsan, Wang, and Qureshi (2016) as they found that firms tend to use their assets tangibility to pay-off their short-term debt and to issue long-term debt. In addition, Ting and Lean (2011) argued that the interest on the short-term debt are more volatile than long-term debt. This indicates that firms try to avoid any risk of uncertain cost by reducing the level of short-term debt and use assets tangibility as collateral to issue long-term debt. Tangibility can be measured by total fixed assets to total assets (Deesomsak et al., 2004).

\subsection{Growth Opportunities}

Growth opportunities refer to the new investment opportunities which can increase the firms' value (Saarani \& Shahadan, 2013). Some previous researches defined growth opportunities in several ways such as percentage changes in total assets (Ahsan et al., 2016; Matias \& Serrasqueiro, 2017; Ting \& Lean, 2011; Titman \& Wessels, 1988) and book value of total assets less the book value of equity plus the market value of equity divided by the book value of total assets (Deesomsak et al., 2004) as measurement of the variables. Pecking Order theory predicts growth opportunities to have a positive relationship with leverage level. This is because growth leads to investment and investment require funds, but firms lack internal fund. Therefore, firm will lose the opportunity to growth if the fund is not sufficient to finance the growth. As equity is costlier than debt, hence, debt is preferred. It is supported by Md-Yusuf et al. (2013) and Hossain and Ali (2012). This implies that firm will lose the opportunity to grow if they do not borrow. Hence, firms prefer to issue debt rather than equity to avoid the fall of the share price. Moreover, banks also tend to provide a loan to the firms that have demonstrated high growth in the business which the firms are able to generate positive cash flow (Ting \& Lean, 2011). Hussain et al. (2015), Md-Yusuf et al. (2013) found that growth opportunities have positive relationship with leverage level. However, Deesomsak et al. (2004) reported that growth opportunities have negative relationship with leverage level for Thailand and Singapore. They argued that firms with high growth opportunities try to avoid the issuing of debt because they do not want to expose themselves to the rules and regulation that have been set by the creditors. Growth opportunities can be measured by annual percentage change in total assets (Ahsan et al., 2016; Kayo \& Kimura, 2011).

\subsection{Earnings Volatility}

Earnings volatility is defined as variability of earnings. According to Trade-off theory, a firm with high volatility of earnings may have a higher probability of being unable to repay debt. This will lead to the higher expectation of financial distress (Deesomsak et al., 2004). Therefore, investors are demanding for a higher rate of return to compensate the risk (Shah \& Khan, 2007). However, firms trying to avoid extra cost will use retained earnings to finance the investment (Shah \& Khan, 2007). Hence, based on the Pecking Order theory, the firm will prefer retained earnings, and in the absence of it, firms issue debt over equity. Therefore, both Trade-off theory and Pecking order theory predicts that earnings volatility has a negative relationship with leverage level, where the 
higher the volatility of earning, the lesser the firms will issue debt. The result is consistent with the finding (Ahmed Sheikh \& Wang, 2011), (G. Huang \& Song, 2006). In addition, (Ahmad \& Wan Aris, 2015) earnings volatility negatively impact leverage level for all measurement including total debt, long-term debt, and shortterm debt. However, (Kumar et al., 2017) found contrasting result between earnings volatility and leverage in European firms. Deesomsak et al. (2004) argued that earnings volatility do not have any significant effect on leverage level. This supports the fact that determinants of capital structure differ from each country in the world. Earning volatility can be measured by standard deviation of earnings before interest and tax to total assets (G. Huang \& Song, 2006; Jong, Kabir, \& Nguyen, 2008).

\subsection{Liquidity}

Liquidity is the ability of an asset to be converted directly into cash without affecting the asset's price to meet short-term needs under a specified acute stress scenario and without the need to readjust basic capital structure (Berkman et al., 2016; Md-Yusuf et al., 2013; Saarani \& Shahadan, 2013). Highly liquid assets will ensure positive working capital, and therefore fund can be saved for future long-term investment without the need to borrow from other external sources. Hence, Pecking Order theory suggests that liquidity has a negative relationship with leverage level. This suggests that firms with highly liquid assets use less debt. This is because whenever the firm requires immediate cash, they can simply liquidate their assets to fulfill the need (Md-Yusuf et al., 2013). Therefore, an internal fund will be preferred instead of the external funds. This finding is in line with (Deesomsak et al., 2004; Md-Yusuf et al., 2013; Shambor, 2017)

Trade-off theory suggests that liquidity has a positive relationship with leverage level. This theory is suggesting that a firm with highly liquid assets should have more debt. This is due to their abilities to repay their debt on time by liquidating their liquid assets despite facing a financial distress (Deesomsak et al., 2004). It is supported by Sabir and Malik (2012) where their study found that liquidity positively impacts leverage levels.

Majority of the past researches conducted found that liquidity has a negative relationship with leverage level which is in line with the Pecking Order theory, suggesting firms to depend less on the external fund and prefer to use retained earnings to finance its investment. Furthermore, Ahmad and Wan Aris (2015) found highly liquid firms use retained earnings to finance its investment regardless of the loan term. Liquidity can be measured by total current assets to current liabilities (Deesomsak et al., 2004; Jong et al., 2008).

\subsection{Firm Size as Control Variable}

According to Alves and Ferreira (2011), the relationship of factors are not the same for all firms when firm size is controlled. Therefore, firm size should be set as a control variable to further confirm the relationship. The firm size can be measured by using the natural logarithm of total assets (Rajan \& Zingales, 1995; Titman \& Wessels, 1988)

\subsection{Dependent Variables}

The capital structure is proxied by leverage level, where it can be measured by total debt, long-term debt, and short-term debt. Most of the past studies focus on a single measure of leverage level which is a total debt to total assets. However, the total debt may comprise of total liabilities which not only include financial debt and leasing liabilities, but also items such as payables, prepayments and other payments which can overestimate the financial leverage (Foo, Abdul Jamal, Abdul Karim, \& Ahmad Baharul Ulum, 2015). Hence, research should decompose the total debt into long-term and short-term debt to get a better insight on the relationship of the independent variables on the dependent variables.

\begin{tabular}{|c|l|l|}
\hline \multicolumn{1}{|l|}{ No } & Leverage & Formula \\
\hline \hline 1 & Total debt to total assets & Total debt to total assets. \\
\hline 2 & Long term debt to total assets & Long term debt divided by total assets. \\
\hline 3 & Short term debt to total assets & Short term debt divided by total assets. \\
\hline
\end{tabular}

The proposed conceptual framework is depicted in figure 1. 


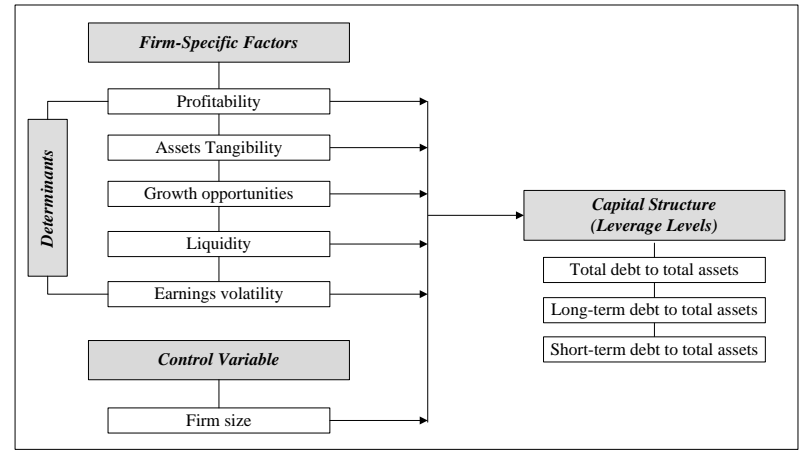

Figure 1: Proposed Conceptual Framework

\section{Methodology}

This study involves in the multivariate dependence technique where distinction of independence and dependence variables are being used to test the hypothesis (Zikmund, Babin, Carr, \& Mitch, 2008). Hence the multiple regression analysis can be used to analyse the multiple independent variables to predict the ratio as metric dependent variables outcomes simultaneously (Zikmund et al., 2008).

\section{Model 1}

$$
\operatorname{TDTA}_{i t}=\alpha+\beta_{1} \mathrm{X}_{i t}+\varepsilon_{i t}
$$

Model 2

$$
\operatorname{LDTA}_{i t}=\alpha+\beta_{1} \mathrm{X}_{i t}+\varepsilon_{i t}
$$

\section{Model 3}

$$
\operatorname{SDTA}_{i t}=\alpha+\beta_{1} \mathrm{X}_{i t}+\varepsilon_{i t}
$$

Where model 1 (Total debt to total assets), model 2 (long-term debt to total assets), and model 3 (Short-term debt to total assets) is the debt ratio for firm $i$ in the year $t, \alpha$ is the intercept of the regression line and $\beta$ stand for coefficiency of independent variables. $\mathrm{X}_{i t}$ is the independent variables (firm-specific factors) of firm $i$ in the year $t . \varepsilon_{i t}$ denoted the error term.

\section{Conclusion}

Given the fact that oil and gas firms play an important role in Malaysia, it is surprising that the relationship of the determinants of capital structure of oil and gas firms have not been discussed rigorously in the academic literature. In addition, it is informative to understand how oil and gas firms make capital structure decision and how it may differ from non-oil and gas firms. Therefore, there is a need to study the determinants of capital structure in the context of oil and gas firms in Malaysia and to conduct a comparative analysis with non-oil and gas firms to better understand it. This study will contribute to the existing literature by understanding the relationship of determinants of capital structure decision specifically for oil and gas firms in Malaysia and how it may differ from non-oil and gas firms. However, this paper needs to be validated through the empirical data collection. 


\section{References}

Ahmad, N., \& Wan Aris, Y. B. (2015). Does Age Of The Firm Determine Capital Structure Decision. Evidence From Malaysian Trading and Service Sector. International Business Management, 9(3), 200-207.

Ahmed Sheikh, N., \& Wang, Z. (2011). Determinants of Capital Structure: An Empirical Study of Firms in Manufacturing Industry of Pakistan. Managerial Finance, 37(2), 117-133.

Ahsan, T., Wang, M., \& Qureshi, M. A. (2016). Firm, Industry, and Country Level Determinants of Capital Structure: Evidence from Pakistan. South Asian Journal of Global Business Research, 5(3), 362-384.

Alves, P. F. P., \& Ferreira, M. A. (2011). Capital structure and law around the world. Journal of Multinational Financial Management, 21(3), 119-150.

Atiyet, B. A. (2012). The pecking order theory and the static trade off theory: Comparison of the alternative explanatory power in French firms. Journal of Business Studies Quarterly, 4(1), 1.

Baker, M., \& Wurgler, J. (2002). Market Timing and Capital Structure. The Journal of Finance, 57(1), 1-32.

Baltaci, N., \& Ayaydin, H. (2014). Firm, country and macroeconomic determinants of capital structure: Evidence from Turkish banking sector. Emerging markets journal, 3(3), 47.

Bauer, P. (2004). Determinants of capital structure: empirical evidence from the Czech Republic. Czech Journal of Economics and Finance (Finance a uver), 54(1-2), 2-21.

Bekaert, G., \& Harvey, C. R. (2017). Emerging Equity Markets in a Globalizing World. Netspar Discussion Paper No. 05/2014-024. Retrieved from Available at SSRN: https://ssrn.com/abstract=2463053 or http://dx.doi.org/10.2139/ssrn.2463053

Berkman, A. N., Iskenderoglu, O., Karadeniz, E., \& Ayyildiz, N. (2016). Determinants of Capital Structure: The Evidence from European Energy Companies. International Journal of Business Administration, 7(6).

Booth, L., Aivazian, V., Demirguc-Kunt, A., \& Maksimovic, V. (2001). Capital structures in developing countries. The Journal of Finance, 56(1), 87-130.

Chipeta, C., \& Deressa, C. (2016). Firm and country specific determinants of capital structure in Sub Saharan Africa. International Journal of Emerging Markets, 11(4), 649-673.

Deesomsak, R., Paudyal, K., \& Pescetto, G. (2004). The Determinants of Capital Structure: Evidence from the Asia Pacific region. Journal of Multinational Financial Management, 14(4-5), 387-405.

Del Sala, B. (2015). Meeting challenges of the oil industry. World Pumps, 2015(4), 28-29. doi:https://doi.org/10.1016/S0262-1762(15)30063-8

Dhingra, R., \& Dev, K. (2016). Determinants of Capital Structure - A Study of Oil Industry in India. International Journal of Engineering and Management Research, 6(1), 35-42.

EIA. (2017). Country analysis brief: Malaysia. Retrieved from U.S Energy Information Administration Independent Statistic and Analysis:

ETP. (2012). Economic Transformation Programme - Annual Report 2012. Retrieved from https://www.pemandu.gov.my/assets/publications/annual-reports/ETP_2012_EN.pdf

Foo, V., Abdul Jamal, A. A., Abdul Karim, M. R., \& Ahmad Baharul Ulum, Z. K. (2015). Capital Structure and Corporate Performance Panel Evidence from Oil and Gas Companies in Malaysia. International Journal of Business Management and Economic Research, 6(6), 371-379.

Geng, J.-B., Ji, Q., \& Fan, Y. (2017). The relationship between regional natural gas markets and crude oil markets from a multi-scale nonlinear Granger causality perspective. Energy Economics, 67, 98-110. doi:https://doi.org/10.1016/j.eneco.2017.08.006

Gisser, M., \& Goodwin, T. H. (1986). Crude oil and the macroeconomy tests of some popular notions. Journal of Money, Credit and Banking, 18(1), 95-103.

Hall, T. W. (2012). The collateral channel: Evidence on leverage and asset tangibility. Journal of Corporate Finance, 18(3), 570-583.

Haron, R. (2014). Capital structure inconclusiveness: evidence from Malaysia, Thailand and Singapore. International Journal of Managerial Finance, 10(1), 23-38.

Hossain, F., \& Ali, A. (2012). Impact of firm specific factors on capital structure decision: an empirical study of Bangladeshi Companies. International Journal of Business Research and Management, 3(4), 163182.

Huang, G., \& Song, F. M. (2006). The Determinants of Capital Structure: Evidence from China. China Economic Review, 17(1), 14-36.

Huang, R., \& Ritter, J. R. (2005). Testing the market timing theory of capital structure. Journal of Financial and Quantitative Analysis, 1, 221-246.

\footnotetext{
* Corresponding author: hana_16005304@utp.edu.my
} 
Hussain, S. S., Hamza, S., \& Miras, H. (2015). The Determinants of Capital Structure for Malaysian Food Producing Companies. International Journal of Accounting, Business and Management, 1(1), 1-25.

IMF. (2018). Malaysia : 2018 Article IV Consultation (IMF Country Report No. 18/61). Retrieved from http://www.imf.org/ /media/Files/Publications/CR/2018/cr1861.ashx Accessed: 29 April 2018

Jong, A., Kabir, R., \& Nguyen, T. T. (2008). Capital Structure Around the World: The Roles of Firm- and Country-Specific Determinants. Journal of Banking \& Finance, 32(9), 1954-1969.

Karadeniz, E., Yilmaz Kandir, S., Balcilar, M., \& Beyazit Onal, Y. (2009). Determinants of capital structure: evidence from Turkish lodging companies. International Journal of Contemporary Hospitality Management, 21(5), 594-609.

Karl, T. L. (2007). Oil-Led Development: Social, Political and Economic Consequence. Encyclopedia of Energy, 4, 661-672.

Kayo, E. K., \& Kimura, H. (2011). Hierarchical determinants of capital structure. Journal of Banking \& Finance, 35(2), 358-371.

Kumar, S., Colombage, S., \& Rao, P. (2017). Research on Capital Structure Determinants: A Review and Future Directions. International Journal of Managerial Finance, 13(2), 106-132.

Matias, F., \& Serrasqueiro, Z. (2017). Are there reliable determinant factors of capital structure decisions? Empirical study of SMEs in different regions of Portugal. Research in International Business and Finance, 40, 19-33. doi:10.1016/j.ribaf.2016.09.014

Md-Yusuf, M., Mohammad Yunus, F., \& Md Supaat, N. Z. L. (2013). Determinants of Capital Structure in Malaysia Electrical and Electronic Sector. International Journal of Social, Behavioral, Educational, Economic, Business and Industrial Engineering, 7(6), 1514-1519.

Mitchell, J. V., \& Mitchell, B. (2014). Structural crisis in the oil and gas industry. Energy Policy, 64, 36-42.

Modigliani, F., \& Miller, M. H. (1958). The Cost of Capital, Corporation Finance and the Theory of Investment. The American Economic Review, 48(3), 261-297.

Myers, S. C. (1984). The Capital Structure Puzzle. The Journal of Finance, 39(3), 575-592.

Myers, S. C. (2001). Capital structure. The journal of economic perspectives, 15(2), 81-102.

Myers, S. C., \& Majluf, N. S. (1984). Corporate Financing and Investment Decisions When Firms Have Information that Investors Do Not Have. Journal of Financial Economics, 13, 187-221.

NTP. (2016). National Transformation Programme - Annual Report 2016. Retrieved from https://www.pemandu.gov.my/assets/publications/annual-reports/NTP_AR2016_ENG.pdf

NTP. (2017). National Transformation Programme - Annual Report 2017. Retrieved from http://www.mampu.gov.my/images/pengumuman/NTP_AR2017_ENG.pdf

Oghenekohwo, A., Theresa, E. N., \& Alice, U. N. (2015). Effect of Capital Structure on Retained Earnings in The Oil and Gas Sector Evidence from Nigeria. Business management and Economics, 3(10), 120132.

Oino, I., \& Ukaegbu, B. (2015). The impact of profitability on capital structure and speed of adjustment: An empirical examination of selected firms in Nigerian Stock Exchange. Research in International Business and Finance, 35, 111-121.

Proença, P., Laureano, R. M., \& Laureano, L. M. (2014). Determinants of capital structure and the 2008 financial crisis: Evidence from Portuguese SMEs. Procedia-Social and Behavioral Sciences, 150, 182-191.

Rajan, R. G., \& Zingales, L. (1995). What do we know about capital structure: Some evidence from international data. The Journal of Finance, 50(5), 1421-1460.

Rawl, L. G. (1987). Adjusting to Variability in the Oil and Gas Industry. Journal of Business Strategy, 7(4), 77-80. doi:doi:10.1108/eb039178

Saarani, A. N., \& Shahadan, F. (2013). The Determinant of Capital Structure of SMEs in Malaysia: Evidence from Enterprise 50 (E50) SMEs. Asian Social Science, 9(6).

Sabir, M., \& Malik, Q. A. (2012). Determinants of Capital Structure- A Study of Oil and Gas Sector of Pakistan. Interdisciplinary Journal of Contemporary Research in Business, 3(10), 395-400.

Shah, A., \& Khan, S. (2007). Determinants of capital structure: Evidence from Pakistani panel data.

Shambor, A. Y. (2017). The determinants of capital structure: Empirical analysis of oil and gas firms during 2000-2015. Asian Journal of Finance \& Accounting, 9(1), 1-34.

Sofat, R., \& Singh, S. (2017). Determinants of capital structure: an empirical study of manufacturing firms in India. International Journal of Law and Management, 59(6), 1029-1045.

Suarez, P. (2016). Determinants of Capital Structure for Listed Companies in the Colombian Industrial Sector. Catalyst, 13(2), 33-45.

Taddese Lemma, T., \& Negash, M. (2013). Institutional, macroeconomic and firm-specific determinants of capital structure: The African evidence. Management Research Review, 36(11), 1081-1122.

The World Bank. (2016). Malaysia. Retrieved from https://data.worldbank.org/country/malaysia Accessed: 28 April 2018

Ting, I. W. K., \& Lean, H. H. (2011). Capital Structure of Government Linked Companies in Malaysia. Asian Academy of Management Journal of Accounting and Finance, 7(2), 137-156. 
Titman, S., \& Wessels, R. (1988). The Determinants of Capital Structure Choice. The Journal of Finance, 43(1), 1-19.

Tongkong, S. (2012). Key Factors Influencing Capital Structure Decision and its Speed of Adjustment of Thai Listed Real Estate Companies. Procedia - Social and Behavioral Sciences, 40, 716-720.

Vo, X. V. (2017). Determinants of capital structure in emerging markets: Evidence from Vietnam. Research in International Business and Finance, 40, 105-113.

Zikmund, W. G., Babin, B. J., Carr, J. C., \& Mitch, G. (2008). Business Research Methods (Eight ed.): SouthWestern Cengage Learning. 